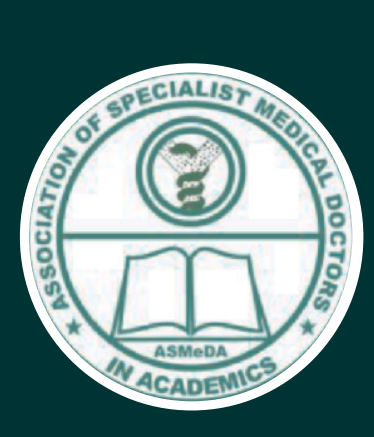

ISSN:Print: 2811-1672

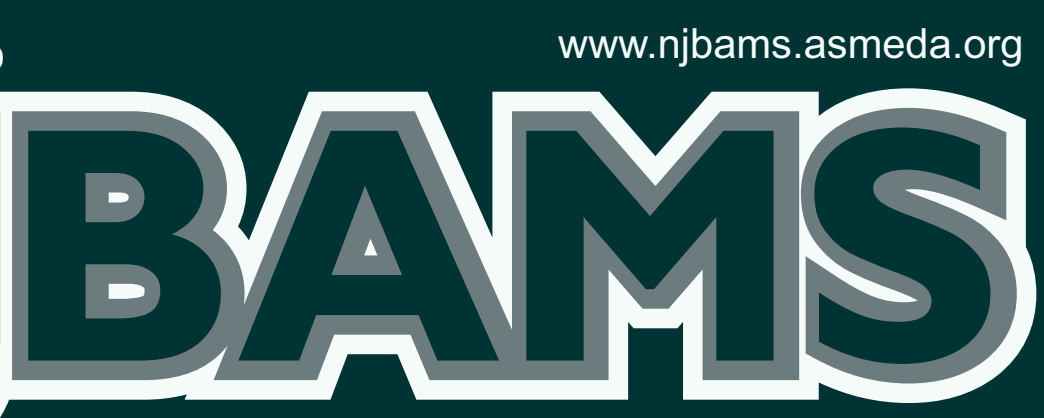

Nigerian Journal of Basic and Applied Medical Sciences

An official publication of the National

ASSOCIATION OF SPECIALIST MEDICAL DOCTORS IN

ACADEMICS (ASMeDA aka MEDSABAMS) 


\title{
The Burden of Obesity in Nigeria
}

\author{
Abubakar M.B. ${ }^{1,2}$, Fatola A.O. ${ }^{3}$, Sanusi K.O. ${ }^{1,2}$, Ibrahim K.G. ${ }^{1,2}$
}

${ }^{1}$ Department of Physiology, Faculty of Basic Medical Sciences, College of Health Sciences, Usmanu Danfodiyo University PMB 2254 Sokoto Nigeria. ${ }^{2}$ Centre for Advanced Medical Research and Training, Usmanu Danfodiyo University PMB 2254 Sokoto, Nigeria.

${ }^{3}$ Department of Physiology, Faculty of Basic Medical Sciences, College of Health Sciences, Ladoke Akintola University of Technology, Ogbomosho, Oyo State, Nigeria.

\begin{abstract}
Background and Aims: Over the years, obesity has become a global health concern. According to the World Health Organization, as at 2016, the world has experienced over four-fold increase in obesity within four decades. This public health crisis has taken its toll in Nigeria with a reported prevalence of $14 \%$ as at 2020 . This review thus seeks to assess available evidence on the burden of obesity, associated co-morbidities, risk of non-communicable diseases, and available management strategies in Nigeria.

Methods: This narrative review was conducted on research articles retrieved without date restriction. The databases assessed were PubMed, Web of Science, Science Direct, and Google Scholar databases, as well as reference lists of relevant articles. The search terms used were "obesity in Nigeria", "burden of obesity" "obesity co-morbidities", and "obesity care."

Results: Studies have indicated that sedentary lifestyle, poor nutritional choices as well as genetic alterations are some of the causes of obesity in Nigeria. With the increasing prevalence of obesity, its associated co-morbidities, the current economic situation of the country and low accessibility to affordable healthcare services, it is currently a burden to healthcare professionals and the country at large.
\end{abstract}

\section{Introduction}

Obesity has become a global health concern as a result of its increasing prevalence among children, adolescents and adults (1). It has been implicated in exerting adverse effects on normal biological, metabolic and psychosocial processes, in addition to being a risk factor for several chronic diseases such as Type-2 diabetes mellitus (T2DM), coronary heart disease, cancers, osteoarthritis, depression and hypertension (2). Obesity is a disease condition characterized by excessive accumulation of body fat due to imbalance between caloric intake and expenditure (3). It is diagnosed as a Body Mass Index (BMI) equaling or above 30 (i.e. $\mathrm{BMI} \geq 30 \mathrm{~kg} / \mathrm{m}^{2}$ ). Overweight, which is closely related to obesity, is described as BMI of $\geq 25-29.9 \mathrm{~kg} / \mathrm{m}^{2}$ (4). Obesity can be classified in terms of the BMI values into three, namely; Class I, Class II and Class III obesity. Class I obesity is defined as BMI range between $30-34.9 \mathrm{~kg} / \mathrm{m}^{2}$. For Class II obesity, the value of the BMI ranges between $35-39.9 \mathrm{~kg} / \mathrm{m}^{2}$ while class III obesity equals $B M I$ value $\geq 40$ (5).

Furthermore, obesity is also classified based on fat distribution, into two major types, central and peripheral obesity (6). Central Obesity is characterized by the predominant distribution of fat to the chest and abdomen. This is common to males and is caused by alterations in fat and glucose metabolism, and associated with diseases such as diabetes mellitus, and cardiovascular disease. Peripheral obesity on the other hand is common to females and is characterized by more fat distribution to the hips and thighs in obese persons (6,7). However, due to reduced inflammation, accumulated fat in the lower body part as seen in peripheral obesity is associated with lesser metabolic imbalance compared to central obesity $(8,9)$.

Several factors have been implicated in the increasing occurrence of obesity, among which are the high socio-economic status of an individual, inadequacy of physical activities, genetic alterations and excessive sugar consumption $(10,11)$.
Conclusions: There is a need for the Nigerian government to focus more on healthcare development to cater for the increasing population and mitigate obesity occurrence. Moreover, there is a need for national orientation and sensitization on predisposing factors to obesity.

Keywords: Nigeria, Obesity, Prevalence, Risk factor, Obesity Care

Corresponding Author: Murtala Bello Abubakar Address: Department of Physiology, Faculty of Basic Medical Sciences, College of Health Sciences, Usmanu Danfodiyo University Sokoto Nigeria. Email: murtala.bello@udusok.edu.ng Phone: +2348035925103

Economic growth of Nigeria like many other countries has influenced the various lifestyles of the inhabitants. This has consequentially contributed to the rising prevalence of obesity and overweight among the population (Figure 1) (12). Nigeria spans over $910,770 \mathrm{~km}^{2}$ on the Western coast of Africa with a population of about 206.14 Million resulting in a population density of approximately 226 people per square kilometer $\left(\mathrm{Km}^{2}\right)$ (13). Nigeria has a relatively even distribution of males and females, with the male population slightly outnumbering that of the females. The ratio of males to females is about 104 males to 100 females i.e. 1.04:1 (13).

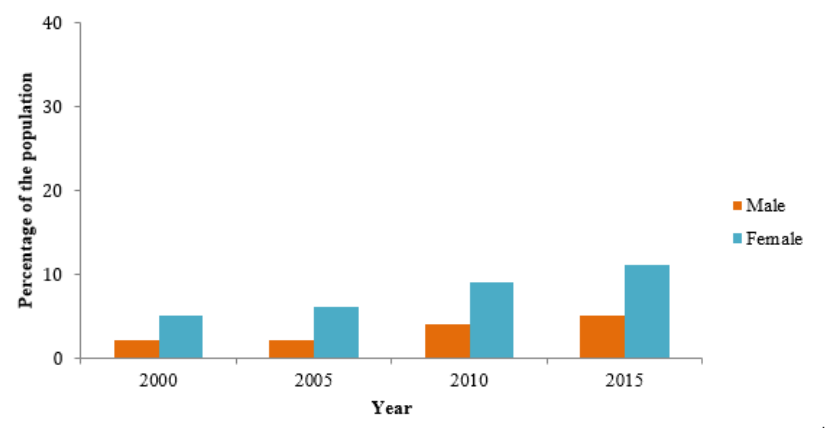

Figure 1: Rising prevalence of obesity among Nigerians (WHO-NCD Country Profiles, 2018)

\section{Prevalence and Incidence of Obesity in Nigeria}

Although there is no definitive record of studies on the national prevalence of obesity in Nigeria, the burden has risen over the years as observed by regional observational studies (14-23) (Table 1). A systematic review has estimated the prevalence of obesity from studies that cover the South-Western, North-Eastern and North-Central regions of Nigeria. Overall, the prevalence of obesity was reported to range between $8.1 \%-22.2 \%$ in adults (24). The highest prevalence of obesity was found in the South-Western region, precisely Lagos, a commercial and highly industrialized city while Maiduguri, the largest city of Borno State in the NorthEastern region had the lowest prevalence (24). A recent metaanalysis also reported a pooled crude prevalence rate of $14.3 \%$ as 
at 2020 (25). Moreover, several other studies in the country, as discussed below, have been conducted to describe the prevalence and probable predisposing factors of obesity in specific regions, between sexes, different age groups and among professionals. It has consistently been reported that obesity is more prevalent amongst females compared to males (26-29). In a study by Akarolo-Anthony and colleagues (30), involving 1058 participants in Abuja, the Federal Capital Territory, which is a city in the North Central region of Nigeria, it was reported that $64 \%$ of the population were obese consisting of $74 \%$ of the total female population and $57 \%$ of the total male population (30). This is in agreement with similar studies by Ejike et al (2015) in Abia state, located in the southeastern part of Nigeria and Sabageh et al (2013) in Osun state, southwestern Nigeria as well as the World Health Organization report for Non-communicable diseases country profile of 2018 (12,22,31,32). Akarolo-Anthony et al (2014) attributed susceptibility to obesity with increasing age and socio-economic status. In the study population, the prevalence ratio for obesity was 8.07 for individuals aged $40-49$ years and 7.74 for individuals who were aged 50 years and above (30). This was further elaborated in studies carried out by Bakari et al (2007) in some localities in Zaria, a city located in Kaduna state, North Western Nigeria and Sola et al (2011) in Benue state, in the North Central region of Nigeria $(32,33)$. High socio-economic status of individuals, increasing level of urbanization and lifestyles were identified as contributing factors to the increasing prevalence of obesity. Introduction of mechanized mode of farming in place of the daily physical rigor of farm practice contributed to the high level of obesity which was reported to be $13.1 \%$ in Zaria and $4 \%$ in some rural and urban communities of Benue State (32,33).

In addition, a study by Ogunjimi and colleagues (34) identified $62.6 \%$ of their study population to be obese. This comprised of nurses in Akwa Ibom, a state located in South-South Nigeria. The study identified nutritional habits and marriage to be contributing factors to the increasing prevalence of obesity in Nigeria (34). Moreover, a study by Duru (2020) (35) found daily consumption of burger to be significantly associated with moderate and morbid obesity in a population of Nigerian immigrants in the United States, as against other factors such as age, level of education, length of stay, acculturation, and perceived stress (35). This highly supports the association of obesity with urbanization and adoption of western lifestyle. Other risk factors that have been identified as contributors to the incidence of obesity in Nigeria include physical inactivity, old age, female gender, poverty, unhealthy fast food consumption, inadequate diet, metabolic disorders and high socioeconomic status (36-39). Worthy of note is that poverty and high socio-economic status appear to co-exist as risk factors of obesity in Nigeria. Obesity has been erroneously termed the disease of affluence due to the record of its prevalence in high-income countries of the world (40). However, the high level of obesity in developing countries like Nigeria especially among those living below poverty line calls for caution. This paradox could be linked to the imitation of western lifestyle through dietary intake, in a bid to portray a false state of pleasure. The low level of awareness on the health consequences of obesity and the belief of the populace that an overweight or obese phenotype is a sign of healthy living also add to the factors leading to the increasing prevalence of obesity in Nigeria.

\section{Health Care Cost of Obesity in Nigeria}

Owing to the absence of an electronic database and inefficient documentation, there is paucity of information on the cost of healthcare services to obese individuals in Nigeria. A hospitalbased study has shown that obese people incur higher expenses when receiving treatments in hospitals than non-obese individuals (49). Generally, obese patients incur an average of $\$ 244$ (equivalent to eighty-eight thousand Nigerian Naira) per annum (49). These expenditures encompass physician consultation, laboratory and radiological tests, cost of medication and alternative health-care services like herbal medicine (49). In addition, the number of days obese individuals are unable to carry out household chores and being absent in employment duty is also significantly higher compared to their non-obese counterparts (49). This by implication adds to the economic burden of obesity in the country. In a recent report, the World Bank has projected that obesity will have a cost implication of over $\$ 7$ trillion in Nigeria and other developing

Table 1. Prevalence of Obesity in Nigerian Population

\begin{tabular}{|c|c|c|c|c|c|c|}
\hline $\mathrm{S} / \mathrm{N}$ & Study Location & Studied Population & $\begin{array}{l}\text { Number of } \\
\text { Participants }\end{array}$ & $\begin{array}{l}\text { Age group } \\
\text { (Years) }\end{array}$ & $\begin{array}{l}\text { Ove rall Preva len ce } \\
(\%)\end{array}$ & References \\
\hline 1 & Abuja & Government workers & 1058 & $>18$ & 64 & $(30)$ \\
\hline 2 & Abia & University students & 2000 & $>19$ & 17 & (22) \\
\hline 3 & Ile-Ife & Secondary school students & 500 & $10-19$ & 4.2 & (41) \\
\hline 4 & Zaria & Residents & 317 & - & 13.1 & (32) \\
\hline 5 & Makurdi and Adikpo & Residents & 435 & $18-45$ & 4 & (33) \\
\hline 6 & Akwa-Ibom & Nurses & 500 & - & 62.6 & (34) \\
\hline 7 & United States & $\begin{array}{l}\text { Nigerian Igbo immigrants in the } \\
\text { United States }\end{array}$ & 178 & $\geq 18$ & 30.1 & (35) \\
\hline 8 & Nnewi & Residents & 1521 & $18-85$ & 26.9 & (42) \\
\hline 9 & Ilorin & Residents & 810 & $\geq 18$ & 9.8 & (14) \\
\hline 10 & Jos & Residents & 902 & $>15$ & 8.7 & (15) \\
\hline 11 & Imo & Hospital patients & 2156 & $18-90$ & 6 & (16) \\
\hline 12 & Katsina & $\begin{array}{l}\text { Residents, hospital staff, and } \\
\text { relation of inpatients }\end{array}$ & 300 & - & 21 & (17) \\
\hline 13 & Ile-Ife & Women in University Community & 236 & $25-60$ & 21.2 & (43) \\
\hline 14 & Uyo & Hospital outpatient & 584 & $18-65$ & 43.9 & (18) \\
\hline 16 & Enugu & Residents & 775 & $18-70$ & 21.2 & (19) \\
\hline 17 & Niger Delta & Residents & 292 & $20-70$ & 49.3 & (45) \\
\hline 18 & Issele-uku & Residents & 200 & $18-60$ & 5.5 & (20) \\
\hline 19 & Ile-Ife & Residents & 777 & $20-90$ & 8.4 & (46) \\
\hline 20 & Lagos & Health workers & 300 & - & 27.3 & (21) \\
\hline 21 & Enugu & Residents & 6683 & $20-60$ & 6.8 & (23) \\
\hline 22 & Benin City & School aged children & 195 & $6-12$ & 3.1 & (47) \\
\hline 23 & Lagos & Secondary school students & 885 & $10-17$ & 9.4 & (48) \\
\hline 24 & Lagos & $\begin{array}{l}\text { Oral and maxillofacial surgery } \\
\text { outpatient }\end{array}$ & 271 & $9-85$ & 11.4 & (37) \\
\hline
\end{tabular}


countries by the year 2035 (50).

\section{Co-morbidities and Mortality}

Obesity is one of the commonest predictors of impaired fasting glucose (51), and is considered as a major risk factor for various non-communicable diseases (NCDs), which in extreme cases become life threatening and may eventually lead to death (52). According to the World Health Organization NCD report for 2018, cardiovascular diseases and cancers, disease conditions in which obesity is one of the known major risk factors, account for $11 \%$ and $1 \%$ respectively out of the $29 \%$ overall mortality by NCDs in Nigeria (Figure 2) (12). The comorbidities that have been shown to be associated with adult and childhood obesity include hypertension, increased blood glucose level, dyslipidemia, diabetes, osteoarthropathies and schizophrenia $(19,47,48,53,54)$. In addition, obesity among other factors have been observed to co-exist in patients living with human immunodeficiency virus (HIV) (55) and increased severity of pain and functional disability in patients with knee osteoarthritis (56) in Nigeria. The maintenance of normal body weight is enjoined due to its potential to prevent the incidence of NCDs, as obesity has been attributed to the burden of postmenopausal breast cancer (57).

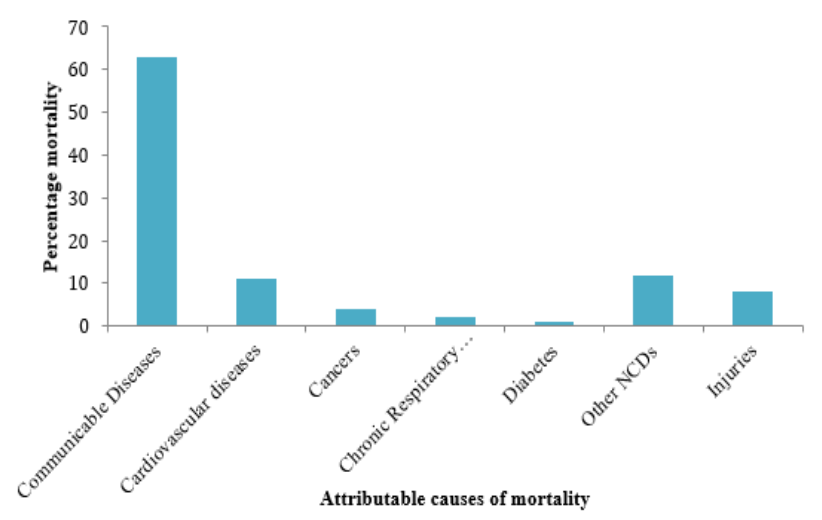

Figure 2: Percentage mortality distribution in Nigeria (WHO-NCD Country Profiles, 2018)

\section{Obesity Prevention and Management Strategies}

Obesity can be effectively prevented through concerted efforts by both individuals and the food industry. For individuals, there is the need to minimize consumption of high caloric foods (fats and sugars) and increase fruits, legumes and vegetable consumption while also actively involving in physical activities (58). The food Industry on the other hand needs to focus on producing healthy foods with low fat, sugar and salt content and the implementation of policies that ensure easy availability, accessibility and affordability $(58,59)$. In agreement with the above roles of individuals and food industry, studies have confirmed that healthy nutrition, active participation in physical activities and substantive weight-loss are key elements in combating obesity $(60,61)$. It was further revealed that these elements reduce the susceptibility of individuals to NCDs, for which obesity is a risk factor. Adoption of long-term weight management plans (such as dietary modification and regular physical activity) in place of short-term extreme plans (such as drug therapy) is also implored for effectiveness. However, bariatric surgery may be required in extreme cases $(60,61)$.

Marriage associated obesity could be curbed by designing public health programs centered on the promotion of healthy marital relationship. Moreover, efforts should be geared towards a new approach on family-based health care delivery, which will consider all associated factors they may influence the patient health (62).
Effective management of obesity has closely been linked to effective weight loss programs that can be achieved through lifestyle modification, drug usage and surgery in extreme cases. Lifestyle modification approach in the management of obesity involves active participation in physical exercises with gradual short-term weight loss goals, consciousness on the type of food consumed and abstinence from high caloric and fat-containing food substances. Additionally, there is the need for self-awareness training such that individuals are self-disciplined to stay away from anything that can lure them to such foods (38).

In addition to the above, Ogunbode et al (2011) also identified the use of some drugs such as methylcellulose, phenteramine, and orlistat in the management of obesity (38). However, the secondary effects of these drugs which might be harmful to the individuals raise high concerns with their usage (38). A number of medicinal plants including onion, garlic, and African cucumber have also been reported to be traditionally used in the management of obesity in Nigeria (63). In extreme cases, surgical procedures such as gastroplasty, gastric bypass, adjustable silicone gastric banding (ASGB), and vertical gastric banding (VGB) are employed (64). However, these surgical procedures are more predominantly performed in developed than in developing countries (38).

In Nigeria, there are no accessible records or databases of healthcare service providers offering surgical procedures aimed at obesity management. Government should therefore encourage private organizations to build and or equip health care centers for bariatric or weight loss surgery in Nigeria. In addition, obese individuals should be encouraged to visit health and fitness clubs with various weight-loss programs that readily offer these services to interested individuals, groups or organizations.

\section{Conclusion}

The prevalence of obesity and consequent increased susceptibility of obese individuals to non-communicable diseases in Nigeria has significantly increased over the years. Considering the effects and potential health and economic burdens posed by obesity, the Government and its development partners should pay more attention to healthcare development in order to mitigate the current trend of increasing prevalence of obesity. Efforts should also be intensified in sensitizing and educating the public to embrace healthy nutritional habits and encouraging active participation in physical activities. More researches are also needed to provide more insights into the genetic and environmental risk factors of obesity that may be peculiar to Nigeria.

\section{Declaration of Competing Interest}

The authors declare no conflict of interest.

\section{References}

1. World Health Organisation. Obesity and overweight fact sheets. 2020; Available from: https://www.who.int/news-room/fact-sheets/detail/obesity-and-over weight

2. Pi-Sunyer X. The medical risks of obesity. Postgrad Med [Internet]. 2009;121(6): 21-33. Available from: https://pubmed.ncbi.nlm.nih.gov/19940414

3. Sikaris KA. The clinical biochemistry of obesity. Clin Biochem Rev [Internet]. 2004 Aug;25(3):165-81. Available from: https://pubmed.ncbi.nlm.nih.gov/ 18458706

4. World Health Organisation. Obesity: preventing and managing the global epidemic. Report of a WHO consultation. Vol. 894, World Health Organization technical report series. Switzerland; 2000.

5. World Health Organisation. Obesity: preventing and managing the global epidemic. In: (WHO Technical ReportS eries 894). Geneva; 2000.

6. Aras Ș, Üstünsoy S, Armutçu F. Indices of Central and Peripheral Obesity; Anthropometric Measurements and Laboratory Parameters of Metabolic Syndrome and Thyroid Function. Balkan Med J [Internet]. 2015/10/01. 2015 Oct:32(4):414-20. Available from: https://pubmed.ncbi.nlm.nih.gov/26740903

7. Haslam DW, James WPT. Obesity. Lancet (London, England). 2005 Oct;366 (9492):1197-209. 
8. Fu X, Song A, Zhou Y, Ma X, Jiao J, Yang M, et al. Association of regional body fat with metabolic risks in Chinese women. Public Health Nutr. 2014 Oct;17(10):2316-24.

9. Brandão I, Martins MJ, Monteiro R. Metabolically Healthy Obesity-Heterogeneity in Definitions and Unconventional Factors. Metabolites [Internet]. 2020 Jan 27;10(2):48.

10. Raman RP. Obesity and Health Risks. J Am Coll Nutr [Internet]. 2002; 21(2): 134S-139S. Available from: https://doi.org/10.1080/07315724.2002.10719210

11. Sahoo K, Sahoo B, Choudhury AK, Sofi NY, Kumar R, Bhadoria AS. Childhood obesity: causes and consequences. J Fam Med Prim care [Internet]. 2015; 4(2):187-92. Available from: https://pubmed.ncbi.nlm.nih.gov/25949965

12. World Health Organisation. Noncommunicable diseases country profiles 2018. World Health Organization. 2018. Available from: https://apps.who.int/iris/ handle/10665/274512

13. World Population Review. Nigeria Population 2020 [Internet]. 2020. Available from: https://worldpopulationreview.com/countries/nigeria-population

14. Desalu O, Salami A, Oluboyo P, Olarinoye J. Prevalence and socio-demographic determinants of obesity among adults in an urban Nigerian population. Sahe Med J. 2008;11(2):61-4.

15. Puepet F, Zoakah A, Chuhwak E. Prevalence Of Overweight And Obesity Among Urban Nigeria Adults In Jos. Highl Med Res J. 2002;1(1):13-6.

16. Iloh GUP, Amadi A, Nwankwo B, Ugwu V. Obesity in adult Nigerians: A study of its pattern and common primary co-morbidities in a rural Mission Genera Hospital in Imo state, south-eastern Nigeria. Niger J Clin Pract. 2011;14(2):212-8.

17. Wahab KW, Sani MU, Yusuf BO, Gbadamosi M, Gbadamosi A, Yandutse MI Prevalence and determinants of obesity - a cross-sectional study of an adult Northern Nigerian population. Int Arch Med [Internet]. 2011;4(1):10. Available from: https://doi.org/10.1186/1755-7682-4-10

18. Idung AU, Abasiubong F, Udoh SB, Ekanem US. Overweight and obesity profiles in Niger Delta Region, Nigeria. African J Prim Heal Care \&amp; Fam Med Vol 6, No 1 (2014)DO - 104102/phcfm.v6i1542 [Internet]. 2014 Jan 28; Available from: https://phcfm.org/index.php/phcfm/article/view/542/801

19. Okafor C, Anyaehie U, Ofoegbu E. The Magnitude of Obesity and its Relationship to Blood Pressure Among the Residents of Enugu Metropolis in South East Nigeria. Ann Med Health Sci Res. 2014;4:624-9.

20. Agofure O. Prevalence of obesity among adults in Issele-Uku, Delta State Nigeria. Alexandria J Med [Internet]. 2018 Dec 1;54(4):463-8. Available from: https://doi.org/10.1016/j.ajme.2017.10.005

21. Iwuala SO, Ayankogbe OO, Olatona FA, Olamoyegun MA, OkparaIgwe U, Sabir AA, et al. Obesity among health service providers in Nigeria: danger to long term health worker retention? Pan Afr Med J [Internet]. 2015 Sep 1;22:1. Available from: https://pubmed.ncbi.nlm.nih.gov/26600902

22. Ejike CECC, Ikwuegu CE, Abalogu RC. Obesity Determined by Differen Measures and its Impact on the Health-Related Quality of Life of Young Adult Nigerians. Asian J Clin Nutr [Internet]. 2015;7:64-75. Available from: https://scialert.net/abstract/?doi=ajcn.2015.64.75

23. Chigbu CO, Parhofer KG, Aniebue UU, Berger U. Prevalence and sociodemographic determinants of adult obesity: a large representative household survey in a resource-constrained African setting with double burden of undernutrition and overnutrition. J Epidemiol Community Health. 2018 Aug;72(8):702-7.

24. Chukwuonye II, Chuku A, John C, Ohagwu KA, Imoh ME, Isa SE, et al. Prevalence of overweight and obesity in adult Nigerians - a systematic review. Diabetes Metab Syndr Obes [Internet]. 2013/01/22. 2013;6:43-7. Available from: https://pubmed.ncbi.nlm.nih.gov/23573067

25. Adeloye D, Ige-Elegbede JO, Ezejimofor M, Owolabi EO, Ezeigwe N, Omoyele C, et al. Estimating the prevalence of overweight and obesity in Nigeria in 2020: a systematic review and meta-analysis. Ann Med [Internet]. 2021 Jan 1;53(1): 495-507. Available from: https://doi.org/10.1080/07853890.2021.1897665

26. Kolotkin RL, Corey-Lisle PK, Crosby RD, Swanson JM, Tuomari A V, L'italien GJ, et al. Impact of obesity on health-related quality of life in schizophrenia and bipolar disorder. Obesity (Silver Spring). 2008 Apr;16(4):749-54.

27. Dickerson FB, Brown CH, Kreyenbuhl JA, Fang L, Goldberg RW, Wohlheiter K et al. Obesity among individuals with serious mental illness. Acta Psychiatr Scand. 2006 Apr;113(4):306-13.

28. Coodin S. Body mass index in persons with schizophrenia. Can J Psychiatry. 2001 Aug;46(6):549-55.

29. Low S, Chin MC, Deurenberg-Yap M. Review on epidemic of obesity. Ann Acad Med Singapore. 2009 Jan;38(1):57-9.

30. Akarolo-Anthony SN, Willett WC, Spiegelman D, Adebamowo CA. Obesity epidemic has emerged among Nigerians. BMC Public Health. 2014 Mav;14:455.

31. Sabageh AO, Ojofeitimi EO. Prevalence of obesity among adolescents in Ile-Ife, Osun state, Nigeria using body mass index and waist hip ratio: A comparative study. Niger Med J [Internet]. 2013 May;54(3):153-6.

32. Bakari A, Onyemelukwe G, Sani B, Aliyu I, Hassan S, Aliyu T. Obesity, overweight and under weight in suburban northern Nigeria. Int J Diabetes Metab. 2007;15:68-9.

33. Sola AO, Steven AO, Kayode JA, Olayinka AO. Underweight, overweight and obesity in adults Nigerians living in rural and urban communities of Benue State. Ann Afr Med. 2011;10(2):139_43.

34. Ogunjimi LO, Ikorok MM, Yusuf OO. Prevalence of obesity among Nigeria nurses: The Akwa Ibom State experience. Int NGO J. 2010;5(2):045-9.

35. Duru AA. Demographic, Lifestyle, and Psychosocial Predictors of Obesity among Nigerian Igbo Immigrants [Internet]. Walden Dissertations and Doctoral Studies. Walden University; 2020.

36. Luke A, Durazo-Arvizu RA, Rotimi CN, Iams H, Schoeller DA, Adeyemo AA, et al. Activity energy expenditure and adiposity among black adults in Nigeria and the United States. Am J Clin Nutr. 2002 Jun;75(6):1045-50.

37. Adeyemo WL, Bamgbose BO, Ogunlewe MO, Ladeinde AL, Taiwo OA. Overweight and obesity among patients attending a Nigerian oral surgery clinic: implications for oral surgical practice in Nigeria. Afr Health Sci [Internet]. 2010 Mar;10(1):40-5

38. Ogunbode AM, Ladipo M, Ajayi IO, Fatiregun AA. Obesity: an emerging disease. Niger J Clin Pract. 2011;14(4):390-4

39. Ogunbode AM, Owolabi MO, Ogunbode OO, Ogunniyi A. Factors associated with obesity and weight reduction among people with obesity: A systematic review. J Mol Pathophysiol. 2020;9(1):1-13.

40. James WPT. The epidemiology of obesity: the size of the problem. J Intern Med. 2008 Apr;263(4):336-52.

41. Sabageh AO, Ogunfowokan AA, Ojofeitimi EO. Obesity and Body Image Discrepancy among School Adolescents in Ile-Ife, Osun State, Nigeria. Pakistan J Nutr. 2013;12(4):377-81.

42. Maruf FA, Udoji N V. Prevalence and Socio-Demographic Determinants of Overweight and Obesity in a Nigerian Population. J Epidemiol [Internet]. 2015/05/23. 2015;25(7):475-81.

43. Ojofeitimi E, Adeyeye A, Fadiora A, Kuteyi A, Faborode TG, Adegbenro C, et al. Awareness of Obesity and its Health Hazard among Women in a University Community. Pakistan J Nutr. 2007;6:502-5.

44. Amodu PHO, Mbah IO, Lawson L. Prevalence of obesity and dyslipidaemia in hypertensives seen in Abuja, Nigeria. Scand J Clin Lab Invest Suppl. 2005; 240:14-7.

45. Adienbo O, Hart VO, Oyeyemi W. High Prevalence of Obesity among Indigenous Residents of a Nigerian Ethnic Group: The Kalabaris in the Niger Delta Region of South-South Nigeria. J Med Sci. 2012;2:152-6.

46. Adebayo RA, Balogun MO, Adedoyin RA, Obashoro-John OA, Bisiriyu LA Abiodun OO. Prevalence and pattern of overweight and obesity in three rural communities in southwest Nigeria. Diabetes Metab Syndr Obes [Internet]. 2014 May 10;7:153-8.

47. Adam VY, Isah JA. Prevalence and comorbidities of childhood overweight and obesity among school aged children in an urban settlement in Benin City, Nigeria. Niger J Paediatr. 2017;44(1).

48. Oduwole AA, Ladapo TA, Fajolu IB, Ekure EN, Adeniyi OF. Obesity and elevated blood pressure among adolescents in Lagos, Nigeria: a cross-sectional study. BMC Public Health [Internet]. 2012;12(1):616.

49. Umar MU, Sanusi A, Garba MR. Comparison of health-care expenditure of obese and non-obese patients attending a tertiary health-care institution in Northwest, Nigeria. Sahel Med J [Internet]. 2016;19(3):125-30.

50. Shekar M, Popkin B. Obesity : Health and Economic Consequences of an Impending Global Challenge. Human Development Perspectives [Internet]. Washington, DC; 2020.

51. Oguoma VM, Nwose EU, Ulasi II, Akintunde AA, Chukwukelu EE, Bwititi PT, et al. Cardiovascular disease risk factors in a Nigerian population with impaired fasting blood glucose level and diabetes mellitus. BMC Public Health. 2017; 17(1):36.

52. Abdelaal M, le Roux CW, Docherty NG. Morbidity and mortality associated with obesity. Ann Transl Med [Internet]. 2017 Apr;5(7):161.

53. Chinedu A, Nicholas A. Hypertension prevalence and body mass index correlates among patients with diabetes mellitus in Oghara, Nigeria. Niger J Gen Pract [Internet]. 2015;13(1):12-5.

54. Amadi O, Okeke I, Ndu I, Ekwochi U, Nduagubam O, Ezenwosu O, et al. Hypertension in children: Could the prevalence be on the increase? Niger Med J [Internet]. 2019;60(5):262-7.

55. Aridegbe M, Adeoye I, Oguntade A. Obesity, hypertension, and dyslipidemia among human immunodeficiency virus patients in Abeokuta Ogun State, Nigeria. Niger J Cardiol. 2019;16(1):83-91.

56. Umar A, Adelowo O, Okpapi J, Omuya U. Effect of obesity on self-reported pain and functional disability in patients with knee osteoarthritis in Zaria, North Western Nigeria. Sub-Saharan African J Med [nternet]. 2018 Apr 1;5(2):52-8.

57. Odutola MK, Olukomogbon T, Igbinoba F, Otu TI, Ezeome E, Hassan R, et al. Cancers Attributable to Overweight and Obesity From 2012 to 2014 in Nigeria: A Population-Based Cancer Registry Study [Internet]. Vol. 9, Frontiers in Oncology . 2019. p. 460

58. Gorski MT, Roberto CA. Public health policies to encourage healthy eating habits: recent perspectives. J Healthc Leadersh [Internet]. 2015 Sep 23;7:81-90.

59. Binks M. The Role of the Food Industry in Obesity Prevention. Curr Obes Rep [Internet]. 2016;5(2):201-7.

60. Bleich SN, Bennett WL, Gudzune KA, Cooper LA. National survey of US primary care physicians' perspectives about causes of obesity and solutions to improve care. BMJ Open [Internet]. 2012 Jan 1;2(6):e001871.

61. Lyznicki JM, Young DC, Riggs JA, Davis RM. Obesity: assessment and management in primary care. Am Fam Physician. 2001 Jun;63(11):2185-96.

62. Wilson SE. Marriage and Obesity: Clinical and Public Health Considerations. J Fam Med Community Heal. 2016;3(5):1095

63. Sidiq LO, Segun PA, Ogbole OO. Medicinal Plants Used in Four Local Government Areas of Southwestern Nigeria for the Management of Diabetes and 
its Comorbidities: An Ethnobotanical Survey. Res Sq [Internet]. 2020; Available from: https://doi.org/10.21203/rs.3.rs-30491/v1

64. Albaugh VL, Abumrad NN. Surgical treatment of obesity. F1000Research [Internet]. 2018 May 21;7:F1000 Faculty Rev-617. Available from: https:// pubmed.ncbi.nlm.nih.gov/29904577 